\title{
ОСОБЛИВОСТІ ЗАСТОСУВАННЯ СТ.З7 ЗУ «ПРО ІПОТЕКУ» ЯК СПОСІБ ЗАХИСТУ ПРАВ ТА ЗАКОННИХ ІНТЕРЕСІВ ІПОТЕКО ДЕРХАТЕЛЯ
}

\author{
ХАТНЮК Наталія Сергївна - доктор юридичних наук, професор, професор \\ кафедри публічного та приватного права Київського університету імені Бориса \\ Грінченка \\ https://orcid.org/0000-0003-3064-7510 \\ ПОБІЯНСЬКА Неллі Борисівна - кандидат юридичних наук, доцент \\ кафедри приватно-правових дисциплін Університет сучасних знань \\ https://orcid.org/0000-0001-5872-9281 \\ DOI 10.32782/NP.2020.4.17
}

\begin{abstract}
У статті розглянуто нормативно-правове регулювання та судову практику реалізаиій договору про задоволення прав іпотекодержателя та іпотечного застереження, як захисту прав та законних інтересів іпотекодержателя. Автор визначає законодавчі гарантї, особливості та передумови переходу права власності на предмет іпотеки до іпотекодержателя.

Ключові слова: іпотека, задоволення вимог іпотекодержателя, іпотечне застереження, захист ицивільних прав, забезпечення виконання зобов'язань, іпотекодержатель, нерухоме майно.
\end{abstract}

Постановка проблеми: вирішуючи питання про стягнення коштів за порушеннями зобов'язанями, які були забезпечені іпотекою, іпотекодержатель намагається обрати найефективніший і оптимальний, 3 точки зору витраченого на нього часу i зусиль та матеріальних ресурсів, спосіб захисту своїх прав та законних інтересів. Законодавець надав кредитору можливіть вибору способів захисту. Один з них, який виглядає найшвидшим, фінансово привабливим і ефективнішим, - іпотечне застереження або договір про задоволення вимог іпотекодержателя. I ще на стадії укладення договору іпотеки сторони передбачають відповідні умови. Проте, незважаючи на всі зусилля копоративних юристів, іпотекодержатель, у разі необхідності звернення стягнення на майно, яке було передане на забезпечення зобов'язань, стикається 3 певними моментами, які частково нівелю- ють позитивний задум законодавця, який був закладений ним у відповідні законодавчі норми. Оскільки все частіше зустрічаються випадки, коли боржники починають зловживати наданими їх законодавцем правами.

Метою цієї статті $є$ висвітлення особливостей застосування іпотечного застереження та виконання договору про задоволення вимог іпотекодержателя як способу захисту його прав та законних інтересів.

Аналіз досліджень і публікацій, у яких започатковано розв'язання цієї проблеми і на які спирається автор

Ця проблематика була предметом досліджень таких науковців, як Ч.Н. Азімов, А.С. Довгерт, М.М. Дякович, О.С. Йоффе, А.В. Журавель, В.М. Коссак, А.С. Аеонова, О.С. Кізлова, Ю.І. Корнієнко, Р.А. Майданик, Х.В. Майкут, І.Б. Новицький, I.I. Пучковська, В.А. Рибачок, Г.Ф. Шершеневич та інші.

Але зміна нормативно-правової бази та судової практики ставить перед дослідницької спільнотою нові завдання, вирішення яких $\epsilon$ нагальною потребою часу.

Виклад основного матеріалу

Аише повне та всебічне забезпечення прав та свобод людини $є$ запорукою стабільного економічного розвитку. Право кожного захищати свої права і свободи від порушень і протиправних посягань будьякими не забороненими законом засобами 


\section{Цивільне, підприсмницьке, господарське та трудове право}

є одним 3 основних прав людини і громадянина, передбачене Конституцією України [1, ст. 55].

3 метою реалізації положень основного закону, Цивільний кодекс України передбачив, що кожна особа має право на захист свого цивільного права у разі його порушення, невизнання або оспорювання [2, ст. $15]$.

Але економічний розвиток не можливий без залучення коштів, зокрема, у формі грошових позик. Найпоширенішою формою гарантування таких позик, станом на сьогодні, є застава. Під час виділення коштів для потреб фізичних осіб або малого та середнього бізнесу кредитори віддають перевагу такому правовому інститут, як «іпотека». I однією 3 переваг такого інституту є «іпотечне застереження» або «договір про задоволення вимог «іпотекодержателя», яке Закон України «Про іпотеку» визначає як договір або відповідне застереження в іпотечному договорі, як можливий спосіб звернення стягнення на предмет іпотеки відповідно до цього закону. Договір про задоволення вимог іпотекодержателя або відповідне застереження в іпотечному договорі, яке прирівнюється до такого договору за своїми правовими наслідками, може передбачати:

- передачу іпотекодержателю права власності на предмет іпотеки в рахунок виконання основного зобов'язання у порядку, встановленому статтею цього Закону;

- право іпотекодержателя від свого імені продати предмет іпотеки будь-якій особі на підставі договору купівлі-продажу у порядку, встановленому статтею цього Закону[3].

Такий договір укладається в письмовій формі і підлягає обов'язкому нотаріальному посвідченню. Закон дозволяє укладення такого договору, як і в момент підписання договору іпотеки, так і передбачає можливість його укладення у будьякий час до моменту вступу в законну силу відповідного рішення суду про звернення стягнення на предмет іпотеки, що можна визнати як додаткову можливість для іпотекодержателя мінімізувати ймовірні ризи- ки під час виконання кредитного договору, забезпеченого іпотекою.

С.В. Нижний відзначає: «Якщо, аналізуючи правову природу застави тільки крізь призму правовідносин, що виникають між заставодержателем та заставодавцем, то їі зобов’язальний характер не викликає сумніву: між сторонами існує правовий зв'язок, який виражається у взаємних правах та обов'язках» [6 с. 106].

У правовій науці розрізняють дві основні форми захисту - юрисдикційну і неюрисдикційну. Про юрисдикційну форму захисту йдеться у разі здійснення захисту цивільних прав державними чи уповноваженими державою органами, тобто у судовому чи адміністративному порядку. Неюрисдикційна форма захисту полягає у самостійних діях уповноваженої особи, спрямованих на захист своїх прав та законних інтересів, тобто без звернення до державних чи інших уповноважених органів [4, с. 331].

Згідно із статтею 33 Закону України „Про іпотеку» у разі невиконання або неналежного виконання боржником основного зобов'язання іпотекодержатель вправі задовольнити свої вимоги за основним зобов'язанням шляхом звернення стягнення на предмет іпотеки. Звернення стягнення на предмет іпотеки здійснюється на підставі:

- рішення суду;

- виконавчого напису нотаріуса;

- згідно з договором про задоволення вимог іпотекодержателя[3].

Захист іпотекодержателем своїх прав та законних інтересів через реалізацію інституту «іпотечного застереження» ми відносимо до неюрисдикційної форми захисту.

Автор погоджується з позицією А.Д. Буханевич, про що держава відіграє «значну роль у забезпеченні передумов, необхідних для нормального функціонування іпотеки та підтримання належного рівня їі безпеки, через нормативно-правове регламентування правовідносин іпотеки. Аише державні інститути дозволяють створити ефективну національну систему реєстрації нерухомого майна та прав на нього» [5, с. 2]. 
3 моменту прийняття Закону України «Про іпотеку» 05.06.2003 року по сьогодні редакція його статей 36 «Позасудове врегулювання» та 37 «Передача іпотекодержателю права власності на предмет іпотеки» неодноразово змінювалась.

Ось їх редакція станом на 14 січня 2006 року:

Стаття 36. Позасудове врегулювання

Сторони іпотечного договору можуть вирішити питання про звернення стягнення на предмет іпотеки иляхом позасудового врегулювання на підставі договору.

Позасудове врегулювання здійснюється згідно із застереженням про задоволення вимог іпотекодержателя, що міститься в іпотечному договорі, або згідно з окремим договором між іпотекодавцем $i$ іпотекодержателем про задоволення вимог іпотекодержателя, який підлягає нотаріальному посвідченню $i$ може бути укладений у будъ-який час до набрання законної сили рішенням суду про звернення стягнення на предмет іпотеки.

Договір про задоволення вимог іпотекодержателя, яким також вважається відповідне застереження в іпотечному договорі, визначає можливий спосіб звернення стягнення на предмет іпотеки відповідно до иъого Закону. Визначений договором спосіб задоволення вимог іпотекодержателя не перешкоджає іпотекодержателю застосувати інші встановлені иим Законом способи звернення стягнення на предмет іпотеки.

Договір про задоволення вимог іпотекодержателя може передбачати:

передачу іпотекодержателю права власності на предмет іпотеки в рахунок виконання основного зобов'язання у порядку, встановленому статтею 37 иъвого Закону;

право іпотекодержателя від свого імені продати предмет іпотеки будь-якій особі на підставі договору купівлі-продажу у порядку, встановленому статтею 38 иъого Закону.

Після завершення позасудового врегулювання будь-які наступні вимоги іпотекодержателя щодо виконання боржником основного зобов'язання є недійсними.

Стаття 37. Передача іпотекодержателю права власності на іпотеки

Договір про задоволення вимог іпотекодержателя, який передбачає передачу іпотекодержателю права власності на предмет іпотеки в рахунок виконання основного зобов'язання, є правовою підставою для реєстраиї права власності іпотекодержателя на нерухоме майно, що є предметом іпотеки.

Рішення про реєстрачію права власносmi іпотекодержателя на нерухоме майно, шо $\epsilon$ предметом іпотеки, може бути оскаржене іпотекодавцем в суді, якщо він доведе, що основне зобов'язання і умови іпотечного договору не були порушені.

у разі переходу до іпотекодержателя права власності на передане в іпотеку нерухоме майно права і вимоги інших осіб на изе нерухоме майно, зареєстровані у встановленому законом порядку, залишаються дійсними. Іпотекодержатель несе відповідальність за задоволення прав чи вимог інших осіб на предмет іпотеки, які мають вищий пріоритет. Задоволення прав чи вимог осіб з нижчим пріоритетом здійснюється у межах перевищення вартості нерухомого майна, визначеної шляхом його оцінки, після задоволення прав чи вимог, які мають вищий пріоритет, над розміром забезпеченой іпотекою вимоги іпотекодержателя [3].

На сьогодні чинною є така редакція: «Стаття 36. Позасудове врегулювання

Сторони іпотечного договору можуть вирішити питання про звернення стягнення на предмет іпотеки шляхом позасудового врегулювання на підставі договору. Позасудове врегулювання здійснюється згідно із застереженням про задоволення вимог іпотекодержателя, що міститься в іпотечному договорі, або згідно з окремим договором між іпотекодавцем і іпотекодержателем про задоволення вимог іпотекодержателя, що підлягає нотаріальному посвідченню, який може бути укладений одночасно 3 іпотечним договором або в будь-який час до набрання законної сили рішенням суду про звернення стягнення на предмет іпотеки.

\{Частина перша статті 36 із змінами, внесеними згідно із Законом № 800-VI від $25.12 .2008\}$

Договір про задоволення вимог іпотекодержателя, яким також вважається відповідне застереження в іпотечному договорі, визначає можливий спосіб звернення 


\section{Цивільне, підприсмницьке, господарське та трудове право}

стягнення на предмет іпотеки відповідно до цього Закону. Визначений договором спосіб задоволення вимог іпотекодержателя не перешкоджає іпотекодержателю застосувати інші встановлені цим Законом способи звернення стягнення на предмет іпотеки.

Договір про задоволення вимог іпотекодержателя або відповідне застереження в іпотечному договорі, яке прирівнюється до такого договору за своїми правовими наслідками, може передбачати:

\{Абзац перший частини третьої статті 36 в редакції Закону № 800-VI від 25.12.2008\}

передачу іпотекодержателю права власності на предмет іпотеки в рахунок виконання основного зобов'язання у порядку, встановленому статтею 37 цього Закону;

право іпотекодержателя від свого імені продати предмет іпотеки будь-якій особі на підставі договору купівлі-продажу у порядку, встановленому статтею 38 цього Закону.

У договорі про задоволення вимог іпотекодержателя або у відповідному застереженні в іпотечному договорі зазначаються:

умови, у разі настання яких іпотекодержатель може використати своє право на позасудове стягнення;

порядок визначення вартості, за якою іпотекодержатель набуває право власності на предмет іпотеки;

прийнятні та належні способи обміну повідомленнями між сторонами договору.

\{Частина четверта статті 36 в редакції Закону № 2478-VIII від 03.07.2018\}

Після завершення позасудового врегулювання будь-які наступні вимоги іпотекодержателя щодо виконання основного зобов'язання:

боржником - фізичною особою є недійсними, якщо інше не визначено договором іпотеки чи договором про надання кредиту, чи договором про задоволення вимог іпотекодержателя;

боржником - юридичною особою або фізичною особою - підприємцем є дійсними, якщо інше не визначено договором іпотеки чи договором про надання кредиту, чи договором про задоволення вимог іпотекодержателя.
\{ Частина статті 36 в редакції Закону № 2478-VIII від 03.07.2018\}

у разі якщо вимоги іпотекодержателя забезпечені декількома предметами іпотеки (у тому числі за декількома договорами іпотеки), а позасудове звернення стягнення здійснюється за рахунок окремого предмета іпотеки, іпотекодержатель має право вимагати (у тому числі шляхом позасудового врегулювання) виконання зобов'язання боржником та/або іпотекодавцем в частині, що залишилася невиконаною після завершення позасудового врегулювання за таким окремим предметом іпотеки.

\{Частина статті 36 в редакції Закону№ 2478-VIII від 03.07.2018\}

Завершенням позасудового врегулювання є державна реєстрація прав власності на всі предмети іпотеки, що виступають забезпеченням за основним зобов'язанням:

за іпотекодержателем (якщо звернено стягнення на предмет іпотеки шляхом набуття його у власність іпотекодержателем);

за покупцем (якщо звернено стягнення на предмет іпотеки шляхом його продажу іпотекодержателем третій особі).

\{Частина статті 36 в редакції Закону№ 2478-VIII від 03.07.2018\}

Стаття 37. Передача іпотекодержателю права власності на предмет іпотеки

Іпотекодержатель може задовольнити забезпечену іпотекою вимогу шляхом набуття права власності на предмет іпотеки. Правовою підставою для реєстрації права власності іпотекодержателя на нерухоме майно, яке є предметом іпотеки, є договір про задоволення вимог іпотекодержателя або відповідне застереженняв іпотечному договорі, яке прирівнюється до такого договору за своїми правовими наслідками та передбачає передачу іпотекодержателю права власності на предмет іпотеки в рахунок виконання основного зобов'язання.

\{ Частина перша статті 37 в редакції Закону № 800-VI від 25.12.2008\}

Договір про задоволення вимог іпотекодержателя чи іпотечний договір, який містить застереження про задоволення вимог іпотекодержателя, є документами, що підтверджують перехід права власності на предмет іпотеки до іпотекодержателя та є 
підставою для внесення відповідних відомостей до Державного реєстру речових прав на нерухоме майно.

\{Статтю 37 доповнено новою частиною згідно із Законом № 2478-VIII від 03.07.2018\}

Право власності іпотекодержателя на предмет іпотеки виникає з моменту державної реєстрації права власності іпотекодержателя на предмет іпотеки на підставі договору про задоволення вимог іпотекодержателя чи відповідного застереження в іпотечному договорі.

\{Статтю 37 доповнено новою частиною згідно із Законом № 2478-VIII від 03.07.2018\}

Рішення про реєстрацію права власності іпотекодержателя на нерухоме майно, що є предметом іпотеки, може бути оскаржено іпотекодавцем у суді.

Іпотекодержатель набуває предмет іпотеки у власність за вартістю, визначеною на момент такого набуття на підставі оцінки предмета іпотеки суб'єктом оціночної діяльності. У разі набуття права власності на предмет іпотеки іпотекодержатель зобов'язаний відшкодувати іпотекодавцю перевищення 90 відсотків вартості предмета іпотеки над розміром забезпечених іпотекою вимог іпотекодержателя.

Право іншої особи з вищим пріоритетом щодо строкового користування нерухомим майном, набутим у власність іпотекодержателем, зберігає чинність відповідно до умов договору, яким обумовлено таке користування. Права та вимоги третіх осіб на предмет іпотеки, набутий у власність іпотекодержателем, які мають нижчий пріоритет, ніж вимога іпотекодержателя, втрачають чинність.

До особи, яка на підставі договору про задоволення вимог іпотекодержателя або застереження про задоволення вимог іпотекодержателя, включеного до іпотечного договору, набула право власності на предмет іпотеки (об'єкт нерухомого майна, об’єкт незавершеного будівництва та майнові права на них), розміщений на земельній ділянці, яка перебуває в оренді іпотекодавця, переходить право оренди на таку земельну ділянку, а зазначений договір про задоволення вимог іпотекодержателя або застереження про задоволення вимог іпотекодержателя, включене до іпотечного договору, є документом, що посвідчує перехід права оренди земельної ділянки до нового власника предмета іпотеки і заміну особи орендаря у договорі оренди землі та підлягає державній реєстрації у встановленому законодавством порядку.

\{Статтю 37 доповнено частиною згідно із Законом № 5059-VI від 05.07.2012\}

\{Стаття 37 із змінами, внесеними згідно із Законом № 3273-IV від 22.12.2005\}»[3].

Станом на сьогодні більшість діючих договорів іпотеки не відповідають чинній редакції Закону України «Про іпотеку», оскільки були укладені за попередніх редакцій вище вказаних норм. Сторони цих договорів не завжди мають спільне волевиявлення і можливість викласти ці договори у новій редакції. Що відповідно вже породжує судові спори. Але логіку і позицію законодавця вже підтримано відповідною судовою практикою:

в постанові Великої Палати Верховного Суду від 21 березня 2018 року у справі № 760/14438/15-ц (провадження№ 14-38цс18) зазначено, що передача іпотекодержателю права власності на предмет іпотеки відповідно до статей 36, 37 Закону України «Про іпотеку» $є$ способом позасудового врегулювання, який здійснюється за згодою сторін без звернення до суду. Застереження в договорі про задоволення вимог іпотекодержателя шляхом визнання права власності на предмет іпотеки - це виключно позасудовий спосіб урегулювання спору, який сторони встановлюють самостійно у договорі. 3 урахуванням вимог статей 328 , 335, 392 ЦК України у контексті статей 36, 37 Закону України «Про іпотеку» суди не наділені повноваженнями звертати стягнення на предмет іпотеки шляхом визнання право власності на нъого за іпотекодержателем [7];

в ухвалі Великої Палати Верховного Суду від 17 березня 2020 року у справі№ 916/3146/17 (провадження № 12-15гс20) та у постанові від 13 лютого 2019 року у справі № 759/6703/16-ц Касаційний цивільний суд у складі Верховного Суду зазначено, що згідно зі змістом статей $1,33,36$ Закону 


\section{Цивільне, підприсмницьке, господарське та трудове право}

України «Про іпотеку» використання позасудового врегулювання способу звернення стягнення на предмет іпотеки відповідно до умови іпотечного договору, яка містить застереження про задоволення вимог іпотекодержателя, незалежно від наявності інших предметів іпотеки по іншим іпотечним договорам, призводить до задоволення вимог кредитора за основним зобов язанням, а тому, Ураховуючи, що іпотекодержатель сам обрав такий спосіб захисту і зареєстрував за собою право власності на предмет іпотеки, суд дійшов висновку про наявність підстав для задоволення позову про припинення договору поруки, який позивач уклав з банком, як додаткове забезпечення зобов 'язань за кредитним договором $[8,9]$;

- свою позицію щодо юридично значимих повідомленьВерховний Суд висловив у Постанові Верховного Суду у складі колегії суддів Другої судової палати Касаційного цивільного суду від 12 червня 2019 року у справі № 344/3627/16-ц (провадження № 61-21032св18)«загальноприйнятим у світовій практиці $\varepsilon$ застосування щодо юридичнозначимих повідомлень принципу «доставки (одержання)» повідомлень, якщо сторони прямо не передбачили застосування принципу «відправлення». Зокрема: (а) у підпункті 3 пункту I.-1:109 Принципів, визначень і модельних правил європейського приватного права вказано, що повідомлення вступає в силу у момент досягнення адресата, якщо 3 нього не слідує більш пізній момент вступу у силу; (б) згідно з пунктами 2, 3 Принципів європейського контрактного права з урахуванням положень пунктів (4) та (5), будь-які повідомлення набирають чинності з моменту, коли вони отримані адресатом. Повідомлення вважається одержаним адресатом, коли його вручено йому за місцем його діяльності або за поштовою адресою, або, якщо він не має місця діяльності або поштової адреси, за місцем його постійного проживання; (в) відповідно до пункту 4 статті 1 Конвенції УНІДРУА про міжнародний факторинг від 28 травня 1988 року письмове повідомлення може бути не підписане, але в ньому обов'язково повинна зазначатись особа, яка його зробила або від імені якої воно зроблене. «Письмове повідомлення» включає телеграми, телекси і будь-які інші види телекомунікаційних повідомлень, які можна відтворити у формі документа, але не обмежується ними. Письмове повідомлення вважається наданим, коли воно отримане адресатом. Підхід стосовно застосування принципу «доставки (одержання)» юридично-значимих повідомлень висловлений і в українській судовій практиці[10]. У постанові Верховного Суду України від 13 квітня 2016 року у справі 6-2988цс15 вказано, що « розглядаючи питання про дотримання під час проведення торгів положень пункту 3.11 Тимчасового положення, суди мають установити, чи було письмово повідомлено, зокрема, боржника про дату, час, місце проведення прилюдних торгів та про стартову ціну, за якою майно пропонується до продажу. При цьому під писъмовим повідомленням слід розуміти не тільки направлення відповідних відомостей зазначеним особам у письмовому виглядi, а й отримання изми особами необхідних відомостей. Отже, загальний зміст поняття «повідомлення» передбачає не тільки направлення відомостей, з якими особу слід ознайомити, а й отримання иією особою зазначених відомостей»[1 1].Засвідчена прачівником кур'єрсъкої служби відмова боржника від отримання письмової вимоги іпотекодавия $\epsilon$ доказом належного повідомлення боржника (постанова ВП ВС від 4 липня 2018 року у справі № 522/2732/16-ц (провадження№ 14- 240цс 18)) [12].

Аналізуючи проведені законодавцем зміни, ми можемо зробити висновок про те, що він

- обмежив права іпотекодержателя на користь іпотекодавця, регламентувавши і деталізуючи порядок повідомлення іпотекодержателя про намір звернути стягнення на предмет іпотеки,

захистив права іпотекодержателя, визначивши, що звернення стягнення на предмет іпотеки або застави шляхом визнання за кредитором права власності на нього, кредитор не втрачає права вимоги до боржника щодо одержання задоволення порушеного основного зобов'язання за рахунок іншого виду забезпечення, 
- $\quad$ хоча ст. 120 Земельного Коксу України і ст. 377 Цивільного кодексу України і закріплювали перехід права користування на земельну ділянку у разі переходу права власності на нерухоме майно, яке на ній розташоване, законодавець ще раз закріпив права іпотекодержателя на користування земельною ділянкою у разі набуття право власності на предмет іпотеки згідно з договором про задоволення вимог іпотекодержателя або застереження про задоволення вимог іпотекодержателя, включеного до іпотечного договору, та закріпив право останнього на проведення державної реєстрації відповідних речових прав на його користь.

Висновки: Однією з особливостей ст. 37 Закону України «Про нотаріат» $є$ її застосування щодо договорів, укладених до зміни редакції вище вказаних статей.

\section{Література}

1. Конституція України : затверджена Законом України від 28 червня 1996 p. № 254к/96-ВР (Із змін., внесеними згідно із Законом України від 1 лютого 2011№ 2952- VI (2952-17) // Відомості Верховної Ради України. - 1996. - № 30. - Ст. 141.; 2011. - № 10. - Ст. 68.

2. Цивільний кодекс України від 16 січня 2003 року [Електронний ресурс]. - Peжим доступу: https://zakon.rada.gov.ua/laws/ show/435-15\# Text

3. Закон України від 05.06. 2003 року № 898-IV «Про іпотеку» [Електронний ресурс]. - Режим доступу: https://zakon.rada. gov.ua/laws/show/898-15\#Text

4. Сидоренко М. В. Виникнення права на захист цивільних прав, свобод та інтересів / М. В. Сидоренко // Актуальні проблеми політики : зб. наук. пр. / гол. ред. С. В. Ківалов ; відп. за вип. $\lambda$. І. Кормич. - Одеса : Національний університет «Одеська юридична академія» : Південноукраїнський центр гендерних проблем, 2012. - Вип. 44. - 392 с. - C. 326-336

5. Буханевич А. Д. Основні напрями реалізації безпеки іпотеки в Українї : автореф. дис. на здобуття наук. ступеня канд. економ. наук : спец. 08.00.08 «Гроші, фінан- си і кредит» / Алла Дмитрівна Буханевич. - Київ, 2011. - 21 с.

6. Нижний С.В. До питання про правову природу застави. Вісник Хмельницького інституту регіонального управління та права. 2002. № 2. С. 104-107.

7. Постанова Великої Палати Верховного Суду від 21 березня 2018 року у справі№ 760/14438/15-ц (провадження № 1438цс18 - Режим доступу: https://reyestr.court. gov.ua/Review/73438185

8. Ухвала Великої Палати Верховного Суду від 17 березня 2020 року у справі№ 916/3146/17 (провадження № 12-15гс20) - Режим доступу: https://reyestr.court.gov.ua/ Review/88376227

9. Постанова від 13 лютого 2019 року у справі № 759/6703/16-ц Касаційний цивільний суд ускладі Верховного Суду- Режим доступу: https://reyestr.court.gov.ua/ $\underline{\text { Review/80487304 }}$

10. Постанова Верховного Суду у складі колегії суддів Другої судової палати Касаційного цивільного суду від 12 червня 2019 року у справі № 344/3627/16-ц (провадження № 61-21032св18)- Режим доступу: https:// reyestr.court.gov.ua/Review/82541266

11. Постанова Верховного Суду України від 13 квітня 2016 року у справі 6-2988цс 15Режим доступу: https://reyestr.court.gov.ua/ Review/57312212

12. Постанова ВП ВС від 4 липня 2018 року у справі № 522/2732/16-ц (провадження № 14- 240цс18- Режим доступу: https:// reyestr.court.gov.ua/Review/75287179

The legislator gives the creditor a choice of ways to protect his rights. One of them, which looks the fastest, most financially attractive and effective - a mortgage clause or agreement on the satisfaction of mortgagee requirements. Moreover, even at the stage of concluding a mortgage agreement, the parties anticipate appropriate conditions. In case of necessity to recover the property that was transferred to secure the obligations, the mortgagee faces certain points that partially neutralizes the positive intention of the legislator, laid down by him in the relevant legislation. The study of the peculiarities of the application of Article 37 of the Law "On Mortgage" as a way to protect the rights and legitimate interests of the mortgagee does not lose its relevance. 


\section{Цивільне, підприсмницьке, господарське та трудове право}

The article considers the legal regulation of the implementation of the agreement on the satisfaction of the rights of the mortgagee and the mortgage clause, as a non-jurisdictional form of protection of the rights and legitimate interests of the mortgagee. The author defines the legal guarantees, features and preconditions for the ownership rights of the mortgage to transfer to the mortgagee on the basis of agreement on the satisfaction of mortgagee requirements or a mortgage agreement which contains warning on satisfaction of the mortgagee requirements, and is a document confirming the transfer of ownership of the mortgage to the mortgagee and is the basis for entering the relevant information into the State Register of Real Property Rights.

Were analyzed changes to the Art. 37 of the Law of Ukraine "On Mortgage", which had been introduced by the legislator in order to detail and regulate the procedure for the ownership of the mortgage transfer to the mortgagee.

As of today, most of the current mortgage agreements do not comply with the current version of the Law of Ukraine "On Mortgage", as they were concluded under previous versions of the above rules. The parties to these agreements do not always have common will and opportunity to set out these agreements in a new version, thus generating litigation accordingly.
The article pays considerable attention to the latest judicial practice of the Supreme Court of Ukraine on the consideration of claims filed in case of disputes arising from mortgage relationships.

Analyzing the changes made by the legislator, the author concludes that at present the legislator

- limited the rights of the mortgagee in favor of the mortgagor, regulating and detailing the procedure for notifying the mortgagee about the intention to recover the mortgage,

- protected the rights of the mortgagee, determining that when applying for recovery of the subject of the mortgage or pledge by recognizing the creditor's ownership on it, the creditor does not lose his right to claim requirement to the debtor for obtaining satisfaction of the violated principal obligation through another type of security,

- the legislator once again consolidated the rights of the mortgagee to use the land in case of acquisition of ownership on the subject of the mortgage under the agreement on satisfaction of the mortgagee's claims or warning on satisfaction of the mortgagee's claims included in the mortgage agreement, and consolidated the latter's right for state registration of real property on mortgagee's benefit. 